Riga, Latvia, March 20, 2020

\title{
TENDENCY OF IMPLEMENTATION OF INFORMATION TECHNOLOGIES INTO PRIMARY SCHOOL
}

\section{Ivan Vasylykiv ${ }^{1}$}

DOI: https://doi.org/10.30525/978-9934-588-39-6-2

At the beginning of the 21st century, the schools in Ukraine already had a rather high degree of computerization in the cities as well as in villages. It is possible, that a lesson, conducted with the help of a multimedia projector, an electronic board, or a computer has a virtuous privilege over a traditionally conducted activity. The school education is focused on the development of a person of a new information society.

Recently, the main place in the teaching of subjects is places by the usual tools - a blackboard, chalk and printed sources (the textbooks, notebooks with printed basis). Thanks to the application of IT, the learning environment is free to supplement video, sound, animation. All this has a significant impact on the sensory field of the primary student, helping to raise cognitive activity, raising interest in the subject and learning in general, intensifying the educational work of students. That is why junior students are now ready to use IT: they know what a computer is, in most cases they can use it, and they do not have a psychological barrier: the children are not afraid that a car will break; they will not have enough knowledge to master it and so on. Still, a car without human factor remains a reasonable pastime. It is now possible that a teacher who facilitates a multimedia projector, an electronic whiteboard, and a computer can use the Internet during the lesson and prepare resources for the class, that have the goodwill of a colleague who uses the «chalk technology» lesson. The education of students in school should be focused on the development of the person of the present information society, and the school should learn to use an unlimited source of information - the Internet, and at least try to teach the child to separate what is good and useful from evil [5, p. 25].

Yuriy Kazakov, studying the pedagogical conditions of using media education in the course of professional education of future elementary school teachers, notes that the term «multimedia» is often used to refer to the sources of information that allow to protect huge amounts of data and cover fairly fast access to them, such as CDs - Compact Disk, DVD - Digital Versatile Video Disk. In other words, the term «multimedia» means both a multimedia shell program and a product invented on the basis of multimedia technology and computer software. At the same time, multimedia is a partial kind of computer

\footnotetext{
${ }^{1}$ Drohobych Ivan Franko State Pedagogical University, Ukraine
} 
technology that combines the usual static visual information (text, graphics) and dynamic - speech, music, video clips, animation) [3, p. 55].

Nowadays, the equipping of higher education institutions with the means of information technology nowadays occupies a significant place in the informatization of higher education. This defines the creation of the following: multimedia computer classes; network connection between the structural units of the educational institution; access to the Internet; educational multimedia products; preparation of teachers for the use of information and telecommunication technologies for educational purposes [2, p. 31].

Viktoriya Imber suggests that the use of multimedia learning tools in the preparation of a future elementary school teacher will play a significant role. For example, multimedia training for future elementary teachers provides:

- increasing sources of obtaining and presenting new information;

- the development of independence and creative thinking in the course of making personal multimedia projects;

- accelerating the pace of learning;

- providing a personal approach to learning [2, p. 59].

- Mastering the multimedia technology by an elementary school teacher is a direct work that assigns three components:

- training (an ability to work with Microsoft PowerPoint);

- methodical (a development of own methodology of carrying out of lessons with use of opportunities of «multimedia technologies»);

- professional (retraining, training teachers with knowledge of the use of «multimedia technologies») [2, p. 63].

Multimedia has a significant place to be applied in the learning process.

The American scientists Fletcher, Dale and Nelson analyzed the traditional forms of teaching and multimedia teaching. Carrying out their own research on their own, scientists came to the conclusion that multimedia curricula occupy a significant place over ordinary, traditional ones [6, p. 21].

The research by Ukrainian scientists (P. Horol [1], R. Hurevych, L. Konyshevskiy, O. Shestopalyuk) indicates the significant chances of multimedia technology. «Eyebrain» - 500 [1, p. 16].

The role of the importance of multimedia technologies was realized by the Polish scientist G. Kedrowicz, who emphasized: «... education gives the better results, the richer the multichannel spectrum of information flow between individual elements of communication» [4, p. 15]. The reason for this is the intelligence of the Eurolinguist Institute (The Netherlands) that most people remember $5 \%$ of what they hear and $20 \%$ of what they see. Simultaneous use of audio and video information increases memory by up to $40-50 \%$ [8, p. 32]. 
This context deserves the attention of the intelligence carried out by Ya. Hayda, S. Yushchyk, B. Syemyeniecki, K. Venta, who revealed that the use of multimedia in education helps to increase the effectiveness of training in relation to regular learning, for example: the effectiveness of training is higher by 56\%; understanding of the topic grows by $50-60 \%$; misunderstandings of knowledge transfer decreased by $20-40 \%$; saving time by $38-70 \%$.

Thus, the consideration of scientific works of domestic and foreign scientists shows that scientists by any way bring to the prospect of the application of their multimedia technologies into the educational process. With multifaceted perspectives, multimedia technologies are being used in various areas of the work of people; the decisive factor among them is education.

\section{References:}

1. Horol, P. K., Hurevych, R. S., Konoshevskyi, L. L. \& Shestopaliuk, O. V. (2004). Suchasni informatsiini zasoby navchannia [Modern informational means of studying]. Vinnytsia: VDPU imeni M. Kotsiubynskoho, 535 p. (in Ukrainian)

2. Imber, V. I. (2008). Pedahohichni umovy zastosuvannia multymediinykh zasobiv navchannia u pidhotovtsi maibutnoho vchytelia pochatkovykh klasiv [Pedagogical conditions of use of multimedia means of teaching in the preparation of the future teacher of elementary school]. Candidate's thesis. Vinnytsia, 238 p. (in Ukrainian)

3. Kazakov, Yu. M. (2007). Pedahohichni umovy zastosuvannia mediaosvity v protsesi profesiinoi pidhotovky maibutnikh uchyteliv [Pedagogical conditions of the use of media education in the process of training of future teachers]. Extended abstract of candidate's thesis. Luhansk, pp. 9-19. (in Ukrainian)

4. Kiedrovich, H. (2000). Otsinka dydaktychnoi prydatnosti vybranykh multymediinykh prohram [Estimation of the didactic suitability of selected multimedia programs]. Pedagogy and psychology of vocational education, no. 2, pp. 83-88. (in Ukrainian)

5. Klymova, K. Ya. (2010). Teoriia i praktyka formuvannia movnokomunikatyvnoi profesiinoi kompetentnosti studentiv nefilolohichnykh spetsialnostei pedahohichnykh universytetiv [Theory and practice of formation of language and communicative professional competence of students of non-philological specialties of pedagogical universities]. Zhytomyr: «Ruta», 560 p. (in Ukrainian)

6. Zabara, S. S., \& Tsurin, O. P. (Ed.). (2003). Multymedia ta multymediini systemy: Konspekt lektsii dlia studentiv spetsialnosti «Prohramne zabezpechennia avtomatyzovanykh system [Multimedia and multimedia systems: A summary of lectures for students of the specialty «Software of automated systems»]. Kyiv: Vydavnytstvo Universytetu «Ukraina», p. 48. (in Ukrainian)

7. Naumenko, H. H., \& Naumenko, O. M. (2008). Pidhotovka vchytelia v umovakh zastosuvannia IKT [Teacher's Training in the Use of ICT]. Computer at school and family, no. 8, pp. 6-10. (in Ukrainian) 
8. Osyn, A. (2005). Multymedya $v$ obrazovanyy [Multimedia in Education]. School library plus, no. 9, pp. 11-24. (in Russian)

9. Smolyaninova, O. G. (2002). Multimedia v obrazovanii (teoreticheskie osnovy $i$ metodika ispolzovaniya) [Multimedia in education (the theoretical foundations and method of use]. Krasnoyarsk: Izd. KrasGU, p. 67. (in Russian)

10. Shyshka, I. V. (2013). Vykorystannia multymediinykh zasobiv navchannia na urokakh $v$ pochatkovykh klasakh: Posibnyk [Using Multimedia Learning Tools at Elementary Classes: A Guide]. Shevchenkove, 250 p. Available at: www.yrok.net.ua/ _ld $/ 21 / 2182$.doc. (in Ukrainian)

\section{PROFESSIONAL TRAINING PHENOMENON IN THE NATIVE VIEWS APPROACH}

\section{Liliia Vinnikova $^{1}$}

DOI: https://doi.org/10.30525/978-9934-588-39-6-3

In the conditions of the modern society development when intercultural and inter-ethnic relations have become of significant importance, the state can be competitive at the international job market only in case this market is provided with highly qualified specialists. Therefore, nowadays the development of higher education in Ukraine is one of the education development priorities.

It should be mentioned as well, certain aspects of the professional training issue study was performed in the following directions, suc as general theoretical and methodological problems of the vocational education system functioning (H. Hrebeniuk, R. Hurevych, I. Ziaziun, I. Kozlovska, N. Nychkalo and others); professional training of the specialists in Ukraine (O. Havryliuk, V. Zaichuk, O. Kiiashko, A. Ligotskyi, P. Oliinyk, M. Pindera and others); development of different types of professional competence of future specialists (V. Barkasi, S. Demchenko, O. Marmaza, T. Matsevko, I. Mischenko and others); psychology of the personality professional development (I. Bandurka, S. Sytnik, K. Chernetski and others); methodology of continuous professional education (S. Hocharenko, T. Desiatov, M. Ievtukh, V. Luhovyi, S. Sysoieva).

The aim of the article is to reveal the meaning of "professional training" in the context of the modern scientific approaches.

\footnotetext{
${ }^{1}$ Institute of Public Administration in the Sphere of Civil Protection, Ukraine
} 